Conference Paper

\title{
Design of Pop-Up Interactive Illustration Book on The Education of Healthy Living Patterns for Children Aged 7-8 Years Old
}

\author{
Mahimma Romadhona*, Aileena S.C.R.E.C \\ Visual Communication Design, Architecture and Design Faculty, Universitas Pembangunan Nasional \\ "Veteran" Jawa Timur, Indonesia
}

*Corresponding author:

E-mail:

mahimma.dkv@upnjatim.ac.id

\begin{abstract}
The long-term objective of this research is the creation of a generation of Indonesians with healthy lifestyle habits, in which children can maintain personal and environmental hygiene to avoid disease attacks. The world is currently experiencing a pandemic due to the Coronavirus (COVID-19) outbreak which attacks humans and can cause death. One of the efforts to prevent the transmission of COVID-19 can be done by adopting a clean and healthy lifestyle. Healthy living habits are mandatory, but in reality, the knowledge and understanding of some people are still low so that people do not live healthily. For this reason, this study aims to educate children about the importance of healthy living interestingly and creatively, namely through the design of an interactive Pop-Up illustrated book for children aged 7-8 years. The method used is a qualitative research method. The design method uses 4 concepts including message concepts, creative concepts, media concepts, and visual concepts. The research process includes primary data collection and secondary data, structured interviews with children's book experts and doctors, as well as field tests and semi-structured interviews with children aged 7-8, namely students in grades 1-2 of elementary school to explore responses and children's understanding of the contents of the book. The sampling technique used is Non-Random Sampling-Purposive Sampling. The final results and conclusions of the study were to produce an Interactive Pop-Up Illustration Book About Healthy Lifestyle Education for 7-8 Years Old Children.
\end{abstract}

Keywords: Illustrations, children's storybooks, pop-ups, healthy life

\section{Introduction}

Healthy living is a condition that greatly determines the quality of human resources (HR). Health or health has a productive value socially and economically, therefore health is an important factor in human life in getting a prosperous life. Education is an excellent approach to imparting an understanding of health and health in all generations. Realizing the importance of health for the welfare of every human being, of course, we all want to live in a healthy condition. However, the reality on the ground shows that creating a healthy condition is not easy, many factors influence it. The lack of knowledge and understanding of some of our society causes them not to live healthy lives. Minister of Health of the Republic of Indonesia, Nila Moeloek said that $82 \%$ of Indonesian families are unhealthy. The statement was taken from a family data collection with 12 healthy indicators, indicating that the national figure was only $18 \%$ of healthy families. We also know that the world is currently experiencing a pandemic due to the Coronavirus (Covid-19) outbreak which attacks humans and can cause death. Indonesia is a country infected with the Coronavirus and currently, the government is making various efforts to prevent the coronavirus and treat/cure affected patients. All elements of society must work together and work together so that

\section{How to cite:}

Romadhona, M., \& Aileena S.C.R.E.C. (2021). Design of pop-up interactive illustration book on the education of healthy living patterns for children aged 7-8 years old. $5^{\text {th }}$ International Seminar of Research Month 2020. NST Proceedings.

pages 369-380. doi: 10.11594/ nstp.2021.0956 
the transmission of this disease does not spread widely and the Coronavirus outbreak is immediately resolved. Various diseases can be prevented by a clean and healthy lifestyle.

Awareness of the importance of maintaining personal and family health is not obtained automatically or spontaneously but is the result of the education a person gets throughout his life which starts early. For that, the Visual Communication Design discipline can play a role in this case. One of them is by educating children about the importance of healthy living interestingly and creatively, namely through the interactive Pop-Up illustrated book media for children aged 7-8 years.

Pop-Up Book is a book containing 3-dimensional illustrated paper that contains interactive elements when opened as if an object had emerged from the book (Hanifah, 2014). The benefit of Pop-Up books is to instill a love of reading in children. In enjoying Pop-Up storybooks, children do not only read a story and see pictures, but children can interact with the stories that are told in the book. So that education about healthy lifestyles to children from an early age can be done in an interesting and fun way. In the future, there will be a generation of Indonesians who have healthy lifestyle habits, namely children who can maintain personal hygiene and the environment.

\section{Material and Methods \\ Time and place}

The research location is in Al-Azhar Kelapa Gading Islamic Elementary School, Surabaya, located in Mulyorejo District, Surabaya. The reason for choosing this school is that it is close to the residence of the head researcher. The research period starts from March to October 2020.

\section{Research methods}

The research method used is qualitative. Qualitative research is flexible and changes according to field conditions. The data obtained is in the form of not numbers, but can be in the form of text, documents, images, photographs, artifacts, or other objects found in the field during the study (Sarwono \& Lubis, 2007). Qualitative research is a process of predicting and confirming, correcting and modifying, suggesting, and defending. Qualitative research is a creative process of processing data so that the analysis pattern becomes clear (Daymon \& Holloway, 2002).

The methods used in this research are:

a. Comparator study, which is a theory for studying media that has similarities with the design that will be made as a reference for the designer in making a book to be made. The book that was used as a comparator study was a pop-up book entitled "The Mermaid Kingdom".

b. Competitor Study, which is a theory to study all the weaknesses and strengths of media that have similarities with the design to be made, it can be said that the media is a competitor in terms of content, layout, drawing style (illustration) to the type of font used from the design to be made.

c. Interview, which is divided into:

1. Structured; which was carried out to 2 sources, namely Children's Book Experts, and doctors. Children's book expert, namely Dr. Riama Maslan Sihombing as a lecturer at the DKV ITB Department who teaches Children's Book Illustration class. General doctor, namely dr. Arifah practices at a hospital in Malang, East Java.

2. Unstructured; which was conducted on 9 children aged 7-8 years by sampling at the Al-Azhar Kelapa Gading Islamic Elementary School Surabaya and its surroundings.

3. Field Test (field test), which is testing pop book media to the target audience before the book is produced. The product is given to the respondent to read and play with, then the researcher records the responses given by the respondent. This field 
test is conducted to measure the extent to which aspects of the media can be understood by respondents. The aspects that are assessed during the field test are the clarity of the storyline, characterizations, story messages, diction, clarity of illustrations, character expressions, pop-up techniques, thickness and type of paper, etc.

\section{Research procedure}

The steps used to compile the research are as follows:

Literature review. Look for literature on the results of previous research related to child illustrations, Child Psychology, and pop-up books. Then collect information that is relevant to the topic or problem that will be or is being researched. This information can be obtained from scientific books, research reports, theses and dissertations, regulations, regulations, school curricula, encyclopedias, and written sources, both printed and electronic.

Collecting primary data and secondary data. Primary data is data from observations of the object of case research and direct data mining at Al-Azhar Islamic Elementary School Kelapa Gading through interviews. Meanwhile, secondary data is data from the results of collecting relevant sources or related to the case object.

\section{Data collection technique}

Interview

An interview is a conversation with a specific purpose. The conversation was carried out by two parties, namely the interviewer (interviewer) who asked the question, and the interviewee (interviewee) who answered the question. (Moleong, 2010). Semi-structured interview, with the following characteristics:

- Open questions, but there are limitations to the theme and flow of the conversation.

- The interview speed is predictable

- Stay flexible

- There is an interview guide that is used as a benchmark in the flow, order, and use of words

- The purpose of the interview is to understand a phenomenon

This method is carried out by direct interviews with the parties concerned according to the desired data. Interviews were conducted with 3 parties, namely, children book experts, doctors, and children aged 7-8 years at Al-Azhar Kelapa Gading Islamic Elementary School Surabaya and its surroundings. Interview material for children's book experts, namely Dr. Riama Maslan Sihombing. The purpose of this interview is to gather information on the principles of making children's illustration books that are attractive and age-appropriate. Furthermore, the second interview was with a general practitioner named dr. Arifah. The interview material was to explore information on how to live healthy for children, what things children should know and do to maintain a clean and healthy lifestyle.

Interviews with respondents were interviews aimed at respondents, namely elementary school children in grades 1 and 2. Furthermore, it can be seen in Figure 1. Respondent interviews were conducted during the field test, which is after the dummy pop-up book was made. The popup book has been bound completely, the script and illustrations have been laid out in such a way that the story can be read by the respondent, but the illustrations have not been given a color, they are still in the form of an outline. This is done so that writers and illustrators have no difficulty if there is a revision of the contents of the story and illustrations after the interviews and field tests are carried out. 

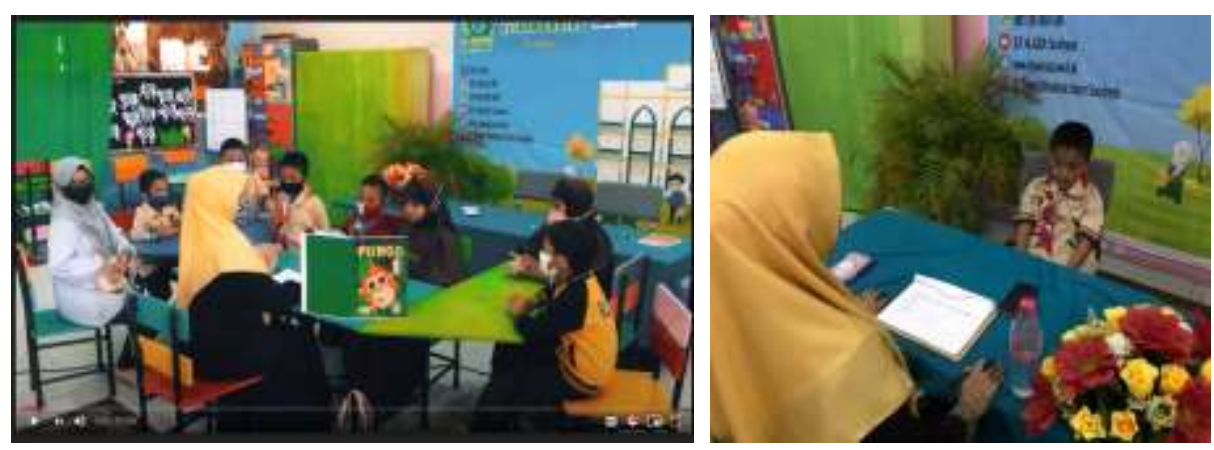

Figure 1. Field tests and interviews with respondents

\section{Literature study}

Systematic identification of findings, and analysis of documents containing information relating to research problems (Consuelo, 1993). This method is used to collect various references regarding illustration, child psychology, book, and journal media studies.

\section{Documentation}

The documentation method is done by collecting data which is done by categorizing and classifying written materials related to the object of the problem. This method is used to document data or literature related to research. The documentation method is used as data in the form of facts and as evidence to be accounted for.

\section{Sampling technique: purposive sampling (non-random sampling)}

This technique is used to determine which respondents will be used for research. To do this, the researcher determines the criteria regarding which respondents can be selected as samples. The criteria referred to describe the demographics of the respondents, for example in terms of age, gender, characteristics, cognitive aspects, language skills, etc. The researcher took the research object, namely students of Al-Azhar Kelapa Gading Islamic Elementary School Surabaya in grades 1 and 2. The number of sample respondents was 9 children, 6 children aged 7 years (grade $1 \mathrm{SD}$ ), and 3 children aged 8 years.

\section{Data analysis technique}

Data analysis was not carried out in just one step after the data was collected. Qualitative data analysis is a systematic process that takes place continuously simultaneously with data collection. Data analysis is a process of organizing, structuring, and interpreting irregular data (Daymon \& Holloway, 2002). The qualitative data in this study were obtained from interviews and other materials. Data analysis is done by organizing the data, describing it into units, synthesizing it, arranging it into patterns, choosing what is important and what will be studied, and making conclusions that can be shared with others. The research data obtained during the research process will be described in descriptive form and conclusions will be drawn.

\section{Interview analysis}

The results of the interviews with respondents were analyzed by making conclusions on the tested variables, then the conclusions were drawn using descriptive narrative analysis.

\section{Results and Discussion Book design concept}

Designing the contents of the book begins with developing a strategy or concept that includes message concepts, creative concepts, media concepts, and visual concepts. 


\section{Concept message}

The concept of the message that will be conveyed in this book is to invite children to know themselves, care, and pay attention to themselves, especially about their health. Children are given insights on how to maintain health, namely by consuming healthy food and drinks, exercising, and maintaining a clean environment both at home and school. Thus, it is hoped that with early education about healthy lifestyles children can find out how to live healthy in a fun way. This message is in line with the Clean and Healthy Behavior (PHBS) health program promoted by the Indonesian Ministry of Health, but not all activity points were carried out. The selected activities are activities that are suitable for children's activities, namely:

a. PHBS at home:

-Wash your hands with soap

- Use clean water

- Use a clean and healthy latrine

- Eradicating mosquito larvae

- Eat fruits and vegetables

b. PHBS at school:

-Wash your hands with soap

- Use a clean and healthy latrine

- Eradicating mosquito larvae

- Eating healthy snacks

- Community service cleaning the school environment

- Throw garbage in its place

- Doing physical activity (exercising)

\section{Creative concepts}

The creative concept in this book is the use of a character named Pongo, a Bornean Orangutan (Pongo pygmaeus). The reason for choosing fable characters is because children have more engagement with animal characters than humans. The reasons for choosing the Orangutan character are first, the similarities between the anatomical shapes of the body and humans, such as toes and hands. Second, because the Bornean Orangutan species is the only member of the great ape family found in Asia, namely in Indonesia and Malaysia, and its population is threatened with extinction (orangutan.or.id). The population of Bornean orangutans is found in the tropical rain forests of Kalimantan, one of which is Gunung Palung, West Kalimantan. Furthermore, it can be seen in Figure 2. This educational book has a mission to introduce this rare species to children. The pongo character is an active and cheerful orangutan like the character of a 7-8-year-old child, so it is hoped that the children will have an emotional closeness to the Pongo character.
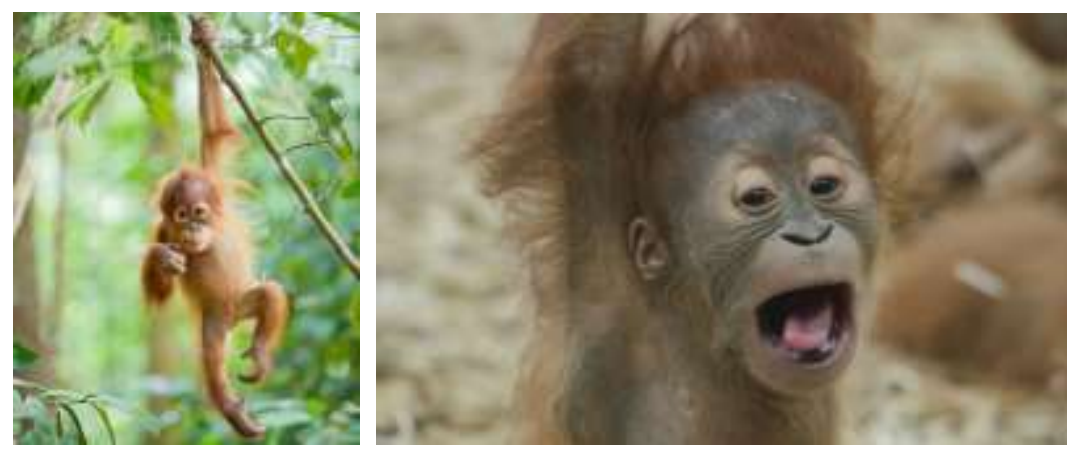

Figure 2. Character reference for the Bornean Orangutan (Pongo pygmaeus) 
The use of place settings uses the setting in the Kalimantan tropical forests where the Orangu$\tan$ species are located. The shape of the house and school is a treehouse. Another creative concept is this illustration book in the form of Pop Up, interactive Lift the flap (opening and closing the window) and equipped with paper toys. Figure 3 shows the brainstorming process in designing creative concepts for this book. The contents of the book consist of 3 scenes, namely the house, school, and garden. This book is an activity book so that children are more interactive with the book by playing the characters in the form of paper dolls in each scene. Children can play the characters in the book according to the available scenes. These scenes show an environment where children should live clean and healthy lives.

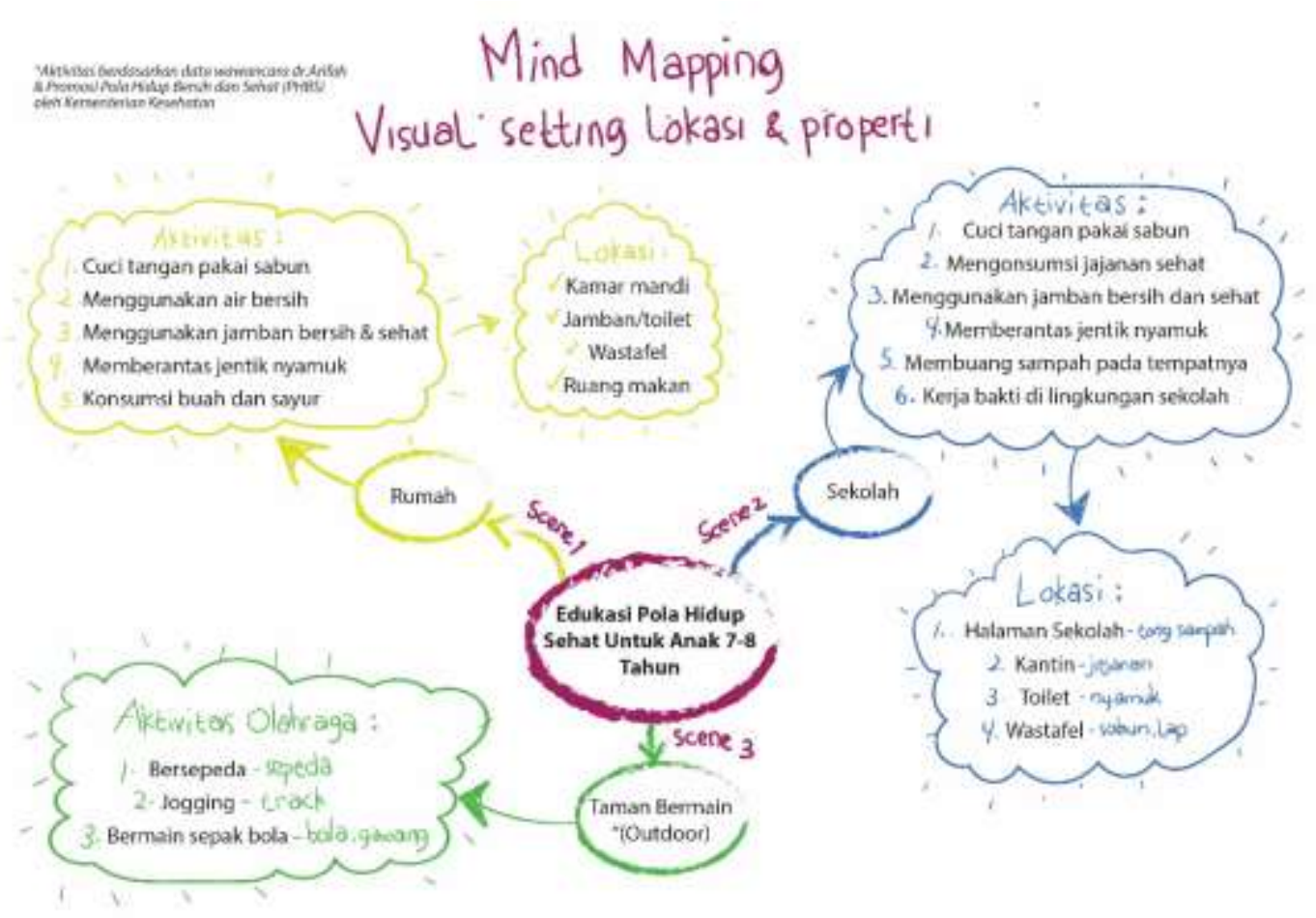

Figure 3. Mind mapping location setting and story properties

Next is the storyline/storyline. The "PONGO" storyline is as follows:

$\checkmark$ Exposition (introduction): namely the stage of introducing the character on the initial page, namely the main character, namely Pongo, and introducing the setting/place of Pongo's residence. Pongo is active in scene 1, which is home. At home, Pongo can do activities such as sleeping, bathing, eating and drinking, washing hands, and cleaning the house.

$\checkmark$ Complication (Conflict): Pongo is active in scene 2, which is school. Pongo meets his friends, namely monkeys, rabbits, rhinos as the mother of the canteen and Owl as the teacher. Activities carried out include healthy snacks in the canteen, washing hands before eating, eradicating mosquito larvae, disposing of trash in their place, and community service cleaning the school grounds. Conflict occurs when the school looks dirty, garbage is scattered because the monkey throws banana peels carelessly, mosquitoes fly, mosquito larvae are in the toilet bath and garbage is washed away in the school gutter.

$\checkmark$ Turning plot (Climax): The rabbit slips because of a banana peel that the monkey throws away. Pongo helps the rabbits and advises Kera to throw the trash into the trash near the canteen. 
$\checkmark$ Ending (Problem-solving): Pongo invites his friends to work together to clean the school using the cleaning equipment available in the cleaning cabinet such as brooms, plant shears, gutter nets, etc. Activities occur in scene 2, namely at school, and in scene 3, namely in the park. After school, Pongo and friends play and exercise in scene 3, namely the jungle garden. Pongo can do activities such as cycling, jogging, swimming, and swinging.

\section{Media Concept}

This educational media is in the form of books. Books are learning media that are close to children, besides their hardcopy forms, have advantages over digital media. Book media can be touched and opened so that it can train the child's fine motor skills. Reading books can also draw closer emotional connections between parents and children. Some things that are considered in the media of this book are:

Carousel Pop-up Technique, which is a pop-up technique where the book can be opened up to 360 degrees with the book standing upright so that the book looks 3-dimensional circular as can be seen in Figure 4.

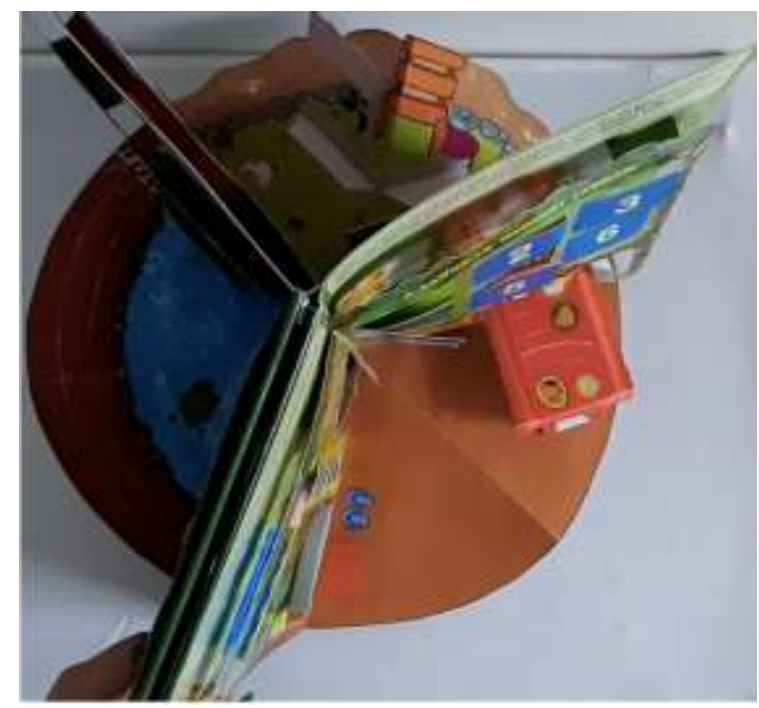

Figure 4. Top view of the carousel pop-up book

Drawing technique; The drawing technique uses manual and digital techniques. Manual techniques with a pencil for sketching and digital techniques using Procreate software, Adobe Illustrator, and Adobe Photoshop. The hardware used is the Ipad and Mac Book Pro.

Papertoys character; As shown in Figure 5, this book is equipped with 15 paper toy characters which children can play in the available scenes while reading the book. So, this book is interactive and children can explore the media according to their imagination.

Page; 10 pages are consisting of 3 scenes/location settings.

Paper; Book cover using hardcover. The contents of the book use 260 gsm and 210 gsm art paper and paper toy characters use 300 gsm art paper with cutting techniques. 

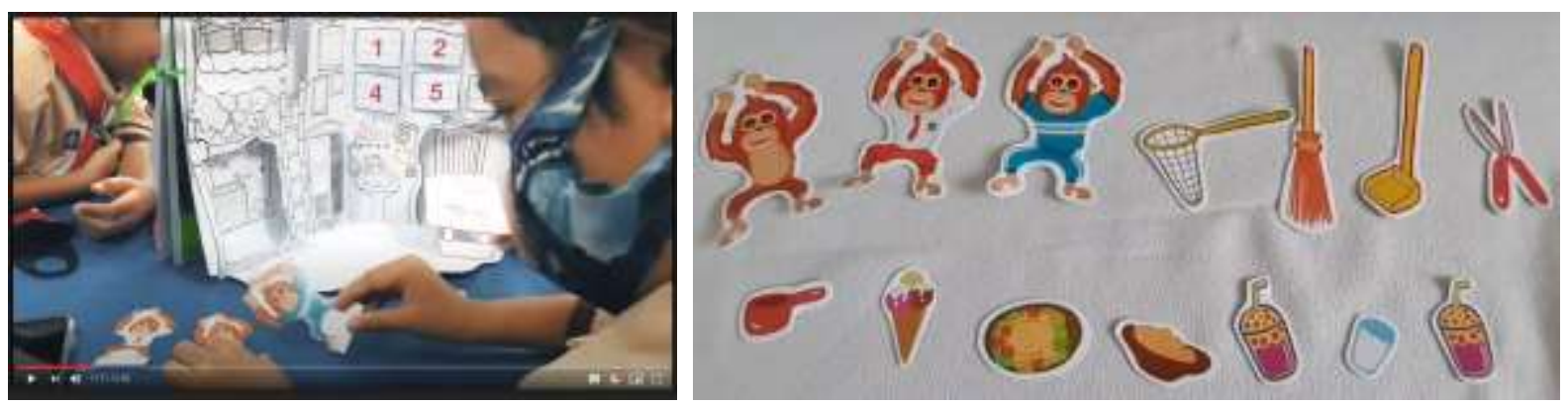

Figure 5. Children's activities while playing with the paper toys character

Visual Concept

The visual concepts in this book include:

$\checkmark$ Drawing style: The drawing style uses a cartoon illustration style with digital painting techniques.

$\checkmark$ Color: The color uses a predominantly green color which indicates the setting in the forest. Besides that, it uses bright and bright colors that show an active and cheerful nuance.

$\checkmark$ Typography: Body text using Acumin Valuable Concept, san serif type (unlinked), size 16 pt. The title uses the Jungle Roar font. The number of sentences per page is 4-7 sentences with 4-7 words per sentence.

$\checkmark$ Layout: The contents of the book use asymmetrical layout with the text at the top of the page and the illustrations below the text. Illustrations dominate the contents of the book by $80 \%$ and text by $20 \%$. This aims to make children more interested in the contents of the book because it is suitable for the child's age, namely 7-8 years, which is included in the category of early readers.

\section{Storybook development}

After the concept is structured in such a way, the next step is to make a storybook. The stages are:

1. Arrange a story script developed from the storyline

2. Create storyboards and sketch illustrations

3. Sketch character designs

4. Inking

5. Coloring

6. Layouting

7. Book production

The script of the story

"Suatu pagi yang cerah di hutan kalimantan, hiduplah seekor Orangutan bernama Pongo. Pongo adalah hewan langka dan dilindungi di Indonesia. Pongo sangat suka hidup bersih dan sehat meski ia hidup di dalam hutan. Yuk, ikuti petualangan Pongo hidup bersih dan sehat saat di rumah, di sekolah dan di taman bermain bersama teman-temannya!

Ini adalah rumah Pongo. Pongo sangat suka hidup bersih dan sehat. Banguntidur Pongo segera bersiap-siap pergi ke sekolah. Saat Pongo akan mandi, Pongo sangat terkejut! Ia melihat sesuatu yang bergerak-gerak di dalam bak mandinya. Hii...ternyata itu jentik nyamuk. Wah, Pongo harus segera menguras bak mandi agar kamar mandinya bersih.

Selesai mandi, Pongo bersiap untuk sarapan. Pongo sangat suka makanan sehat seperti yang tersaji di meja makannya. Wah, perut Pongo sudah lapar nih. Namun, Pongo tak lupa mencuci tangan sebelum dan sesudah makan.

Usai sarapan, Pongo berangkat ke sekolah. Ini adalah sekolah rimba. Sekolah Pongo asyik sekali, ada kelas di atas pohon dan ada kantin sehatnya juga lho. Bu Badak menyiapkan makanan 
dan minuman bergizi untuk murid-murid. Semua jajanan di kantin sehat karena makanannya tertutup, sehingga tidak ada kotoran dan lalat yang hinggap. Murid-murid juga selalu mencuci tangan sebelum dan sesudah jajan.

Tong sampah juga disediakan di sekolah. Tapi, ada si Kera yang membuang kulit pisang sembarangan nih, akibatnya si kelinci jatuh terpeleset. Aduh, kasihan sekali ya. Pongo pun segera menolongnya. Hari ini adalah jadwal kerja bakti membersihkan sekolah. Pongo dan teman-teman bergotong-royong membersihkan sekolah. Pongo merasa senang dan nyaman saat sekolahnya bersih dan sehat.

Sore hari sepulang sekolah, Pongo dan teman-temannya asyik bermain dan berolahraga di taman rimba. Ada yang berenang, berlari, bersepeda, dan berayun. Olahraga membuat badan sehat. Pongo sangat suka berolahraga. Olagraga kesukaannya adalah bersepeda dan berayun. Demikianlah aktivitas Pongo sehari-hari. Ia selalu menjaga kesehatan dengan cara hidup bersih dan sehat saat di rumah, sekolah dan sekitarnya".

\section{Character design sketches}

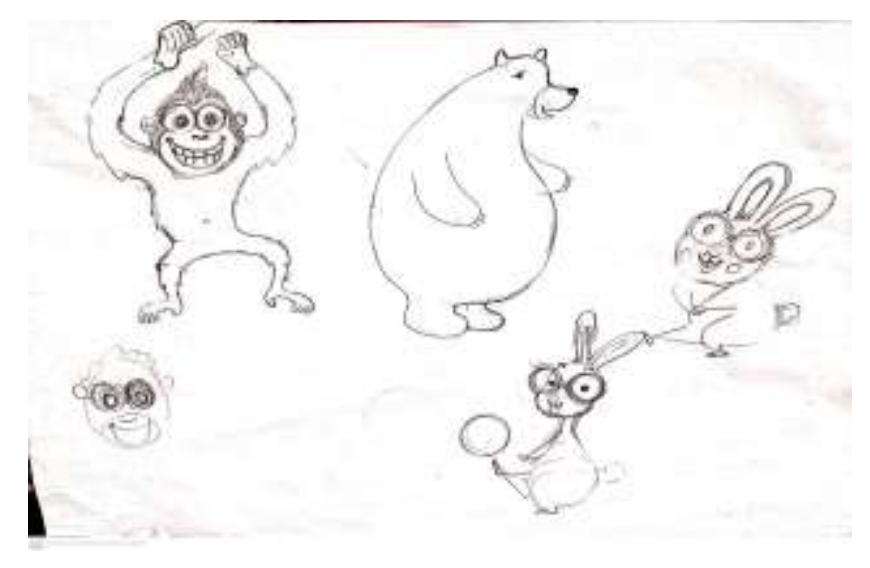

Figure 6. Character design sketches
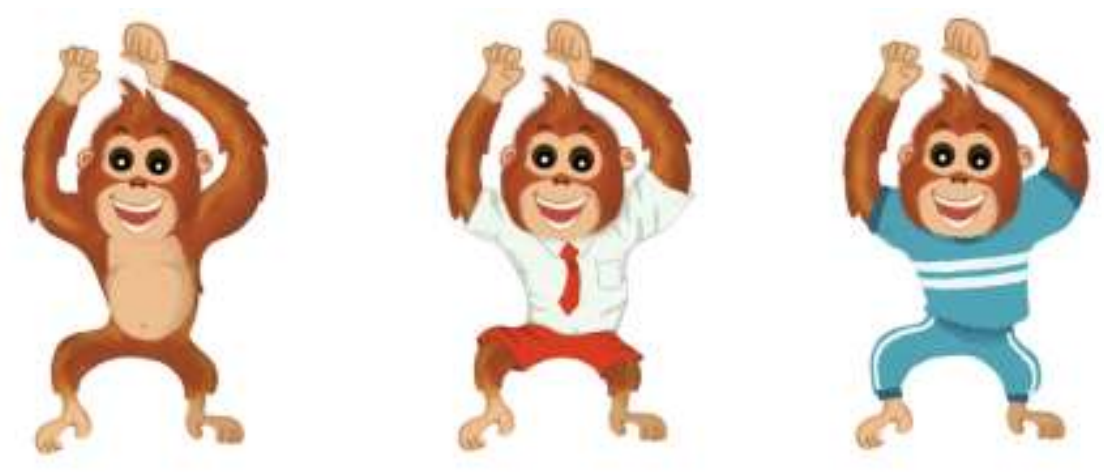

Figure 7. Coloring character designs

Rough design

A rough design is a rough design in the form of an outline. The design is made using digital painting techniques but has not been colored. This design is then produced into a dummy pop-up book which is then used for field tests. 

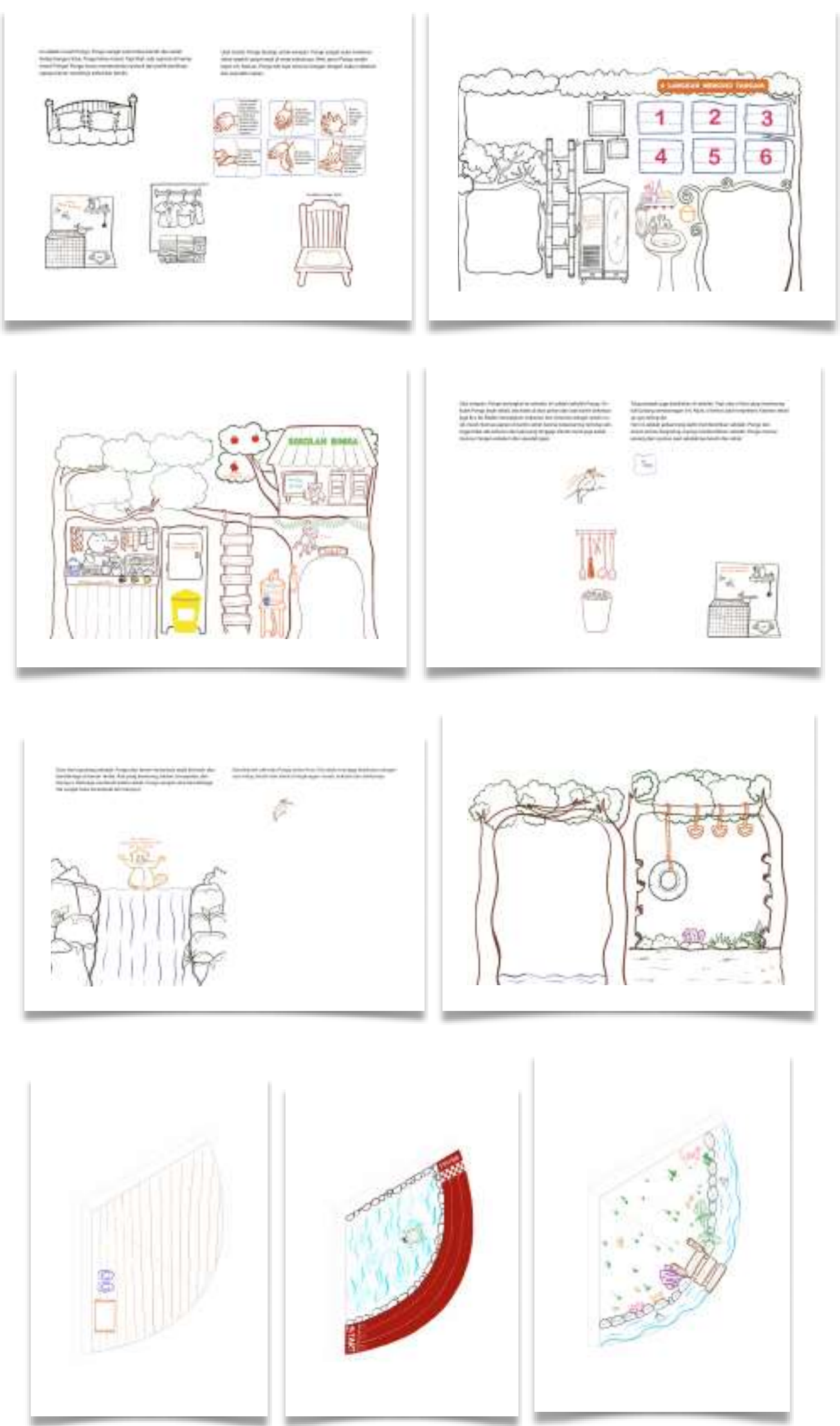

Figure 8: Pop-up book rough design 


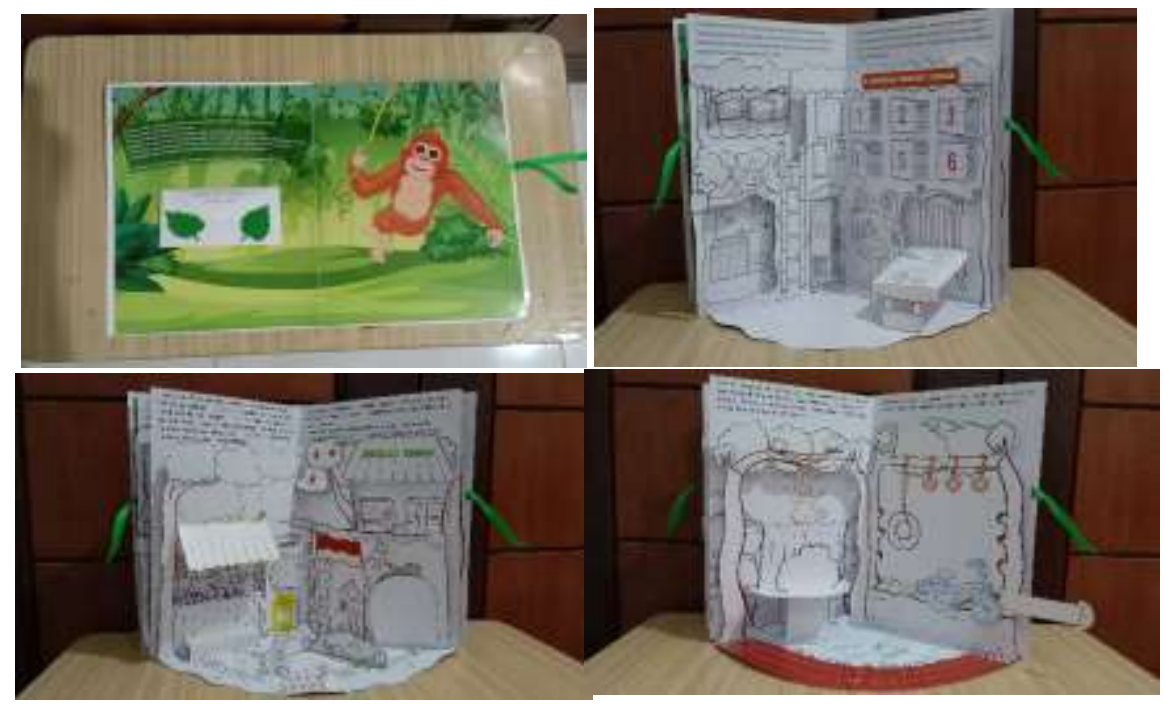

Figure 9. Pop-up book dummy photo

\section{Final design}

The final design is the final design, which is an image that has been colored using digital painting techniques. The following is the final design produced:
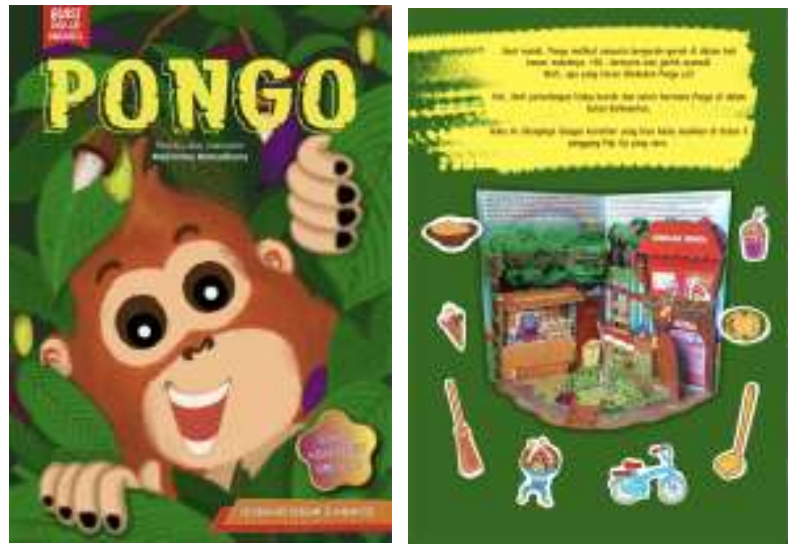

Figure 10. Front and back cover design
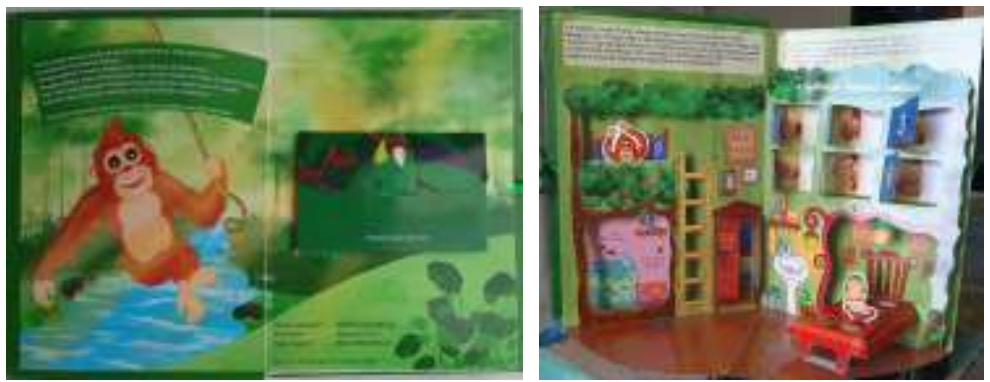

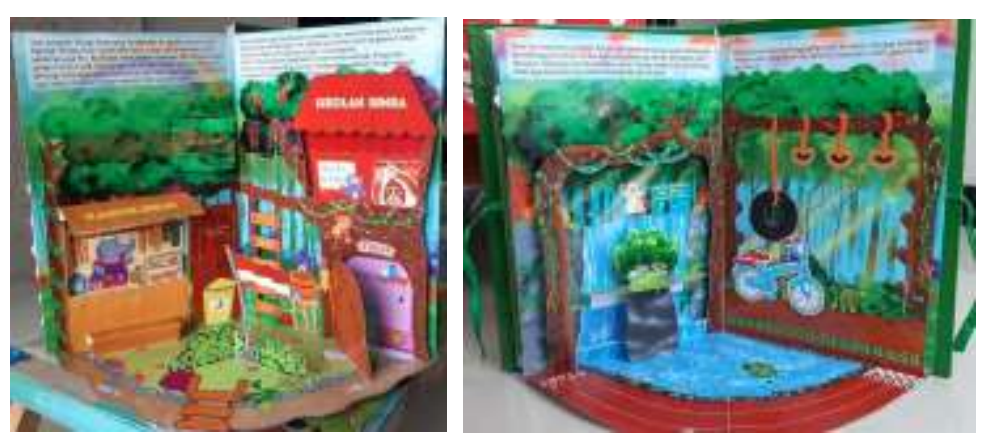

Figure 11. Book content design

\section{Conclusion}

The results of the study can be concluded that:

$\checkmark$ Education about clean and healthy living habits (PHBS) for children can be done in an interesting, fun, and interactive way, namely through a pop-up carousel book equipped with paper toy characters.

$\checkmark$ Design concepts, namely message concepts, creative concepts, visual concepts, and media concepts must be prepared with careful thought based on an approach to children's characteristics.

$\checkmark$ The method of field testing (field testing) should be carried out by researchers in the field of design who have a target audience of children. Field tests on children's book design are very important before the book is produced so that books that are published are not only interesting according to the drafter but also interesting for children.

\section{Acknowledgment}

The author would like to thank the Institute for Research and Community Service (LPPM) UPN "Veteran" Jawa Timur, which has funded basic research on the design of interactive pop-up books about education on Clean and Healthy Living Behaviors, so that science in the field of children's book illustration can be developed. Thanks are also conveyed to Nur Latifatuz Zakiyah as the engineering paper and Septian Anom who has helped document the field test process during field research.

\section{References}

Consuelo. (1993). Metodologi penelitian. Jakarta: Universitas Indonesia.

Daymon, C., \& Holloway, I. (2002). Qualitative research methods in public relations \& marketing communications. Terjemahan: Cahya Wiratama. Bandung: Mizan Media Utama.

Hanifah, T. U. (2014). Pemanfaatan media pop-up book berbasis tematik untuk meningkatkan kecerdasan verbal-linguistik anak usia 4-5 tahun (studi eksperimen di TK Negeri Pembina Bulu Temanggung). BELIA: Early Childhood Education Papers, 3(2), 10-15.

Moleong, L. J. (2010). Metodologi penelitian kualitatif. Bandung: PT Remaja Rosdakarya.

Peraturan Kementerian Kesehatan Republik Indonesia Nomor 2269/MENKES/PERXI/2011. Pedoman Pembinaan Perilaku Hidup Bersih dan Sehat (PHBS).

Sarwono, J., \& Lubis, H. (2007). Metode riset untuk desain komunikasi visual. Yogyakarta: Andi

www. orangutan.or.id (accessed at 22nd March 2020) 